\title{
KRZYSZTOF NIERZWICKI
}

ORCID: 0000-0002-6860-1764

Biblioteka Uniwersytecka w Toruniu

\section{EGZEMPLARZ DRUGIEGO WYDANIA DE HUMANI CORPORIS FABRICA ANDREASA VESALIUSA (BAZYLEA 1555) W ZBIORACH KSIĄŻNICY CIESZYŃSKIEJ W CIESZYNIE. CZĘŚĆ I. W ZBIORACH EZECHIASA I GEORGA REICHÓW (II POŁOWA XVI WIEKU - POCZĄTEK XVII WIEKU)}

De humani corporis fabrica w zbiorach polskich. Charakterystyka księgozbioru i życiorys Georga Reicha starszego. Życiorys pierwszego właściciela cieszyńskiego egzemplarza De humani corporis fabrica - Ezechiasa Reicha (1532-1572). Życiorys pierwszego spadkobiercy egzemplarza — Georga Reicha młodszego (1568-1616/1620).

SŁOWA KLUCZOWE: Cieszyn, Książnica Cieszyńska, Georg Reich st., Ezechias Reich, Georg Reich mł., Andreas Vesalius, De humani corporis fabrica.

Andreas Vesalius (1514-1564) $)^{1}$ należał do najwybitniejszych lekarzy europejskich wszech czasów, a dzięki dwukrotnej publikacji swego najważniejszego dzieła De humani corporis Fabrica (Bazylea 1543 i 1555) uznawany jest za twórcę nowoczesnej anatomii. Dzieło to wydane zostało z niezwykłą starannością i kunsztem typograficznym w bazylejskiej oficynie Johannesa Oporinusa w łącznym nakładzie około 1400 woluminów (Margócsy, Somos, Joffe, 2018, s. 9). Według współczesnych badań do chwili obecnej przetrwała około połowa z obu nakładów, to jest nieco ponad 700 woluminów (Margócsy, Somos, Joffe, 2018, s. 8). Spośród nich 19 znajduje się w zbiorach trzynastu bibliotek polskich, zlokalizowanych w dziesięciu miejscowościach (Nierzwicki, 2016, s. 167-203; Margócsy, Somos, Joffe, 2018, s. 202-203, 355-365). Jedną z nich jest położone na pograniczu Czech

${ }^{1}$ Obszerny biogram A. Vesaliusa i najnowszą literaturę zob. Nutton, 2014, s. LXXV-CIII; w języku polskim znaczący tekst biograficzny opublikował Kazimierz S. Jędrzejewski (2013, s. 155-206). 
i Polski urokliwe miasto Cieszyn ze wspaniałą, historyczną biblioteką - Książnicą Cieszyńską. W jej zasobach przechowuje się ciekawy pod względem proweniencji egzemplarz drugiej edycji tego dzieła.

Prześledzenie losów, jakie stały się udziałem interesującego nas woluminu, od chwili opuszczenia warsztatu bazylejskiego impresora aż do momentu, kiedy znalazł się w zbiorach Książnicy Cieszyńskiej, będzie podstawowym celem badań, których wyniki zostaną zaprezentowane w niniejszym artykule, z konieczności podzielonym na dwie części ${ }^{2}$ : część I, W zbiorach Ezechiasa i Georga Reichów (II połowa XVI wieku - początek XVII wieku), i część II, W kolekcji Leopolda Jana Szersznika (1747-1814). Pozwolą one na przybliżenie recepcji osiągnięć naukowych Vesaliusa na dawnym i współczesnym obszarze Rzeczypospolitej. Temat losów zachowanych w Polsce egzemplarzy De humani corporis Fabrica ma już całkiem sporą, choć nadal niewystarczającą, literaturę. Znajdujący się we wrocławskim Ossolineum „królewski” egzemplarz pierwszego wydania (1543) omówili pod kątem tegumentologicznym badacze z Wrocławia i Torunia, Dorota Sidorowicz-Mulak i Arkadiusz Wagner (2015, s. 3-24). Cztery inne egzemplarze — znajdujące się w zbiorach Biblioteki Narodowej w Warszawie, Biblioteki Uniwersyteckiej w Toruniu, Biblioteki Gdańskiej Polskiej Akademii Nauk i Biblioteki Seminarium Duchownego w Olsztynie — poddał analizie autor tych słów w latach 2016-2021 (Nierzwicki, 2016; 2019a; 2019b; 2021a; 2021b). Kwestią oprawy egzemplarza z Biblioteki Elbląskiej zajęła się specjalistka w zakresie konserwacji książki, Ewa Chlebus (2016). Zatem trzynaście kolejnych woluminów przechowywanych w polskich bibliotekach jest kompletnie pozbawionych szerszych omówień w literaturze, niewątpliwie zaś przynajmniej część z nich absolutnie zasługuje na pogłębione opracowanie naukowe. Tak jest i w wypadku egzemplarza znajdującego się dzisiaj w Książnicy Cieszyńskiej³, jednym z najciekawszych i najbogatszych tego typu miejsc na południu Rzeczypospolitej ${ }^{4}$.

2 Podział tekstu na dwie części został wymuszony względami formalnymi. Przede wszystkim wynikał z braku dostępu do części źródeł przechowywanych w Książnicy Cieszyńskiej. Zaplanowana kwerenda w tej bibliotece (pierwsza miała miejsce w 2019 roku) przed oddaniem tekstu do druku nie mogła dojść do skutku ze względu na pandemię COVID-19. Drugim powodem podzielenia artykułu na dwie części jest jego obszerność. W całości tekst miałby ponad 120 tysięcy znaków.

${ }^{3}$ Książnica Cieszyńska, sygn. SZ K I 01; egzemplarz przechowywany tam nie był przedmiotem osobnych studiów naukowych. Najszerszy dotychczas opis woluminu dali autorzy światowego spisu Fabrica (zob. Margócsy, Somos, Joffe, 2018, s. 355-356). Wzmiankowany jest on również w szeregu publikacji (także elektronicznych) o charakterze popularnonaukowym, przewodnikach i katalogach wystaw; zob. między innymi Kleczek, Rusnok, 2010, s. [4], a także De humani corporis fabrica libri septem. Najstynniejsze XVI-wieczne dzieto o anatomii człowieka, [wystawa i prelekcja w Książnicy Cieszyńskiej z cyklu Cymelia i osobliwości w zbiorach Książnicy Cieszyńskiej, 2018], https://kc-cieszyn.pl/de-humani-corporis-fabrica-libri-septem-najslynniejsze-xvi-wieczne-dzielo -o-anatomii-czlowieka/ (dostęp: 10.06.2021).

${ }^{4}$ Biblioteka Cieszyńska, a zwłaszcza osoba jej założyciela Leopolda Jana Szersznika, doczekała się wielu opracowań. Szerzej na jej temat w drugiej części niniejszego artykułu, zob. 


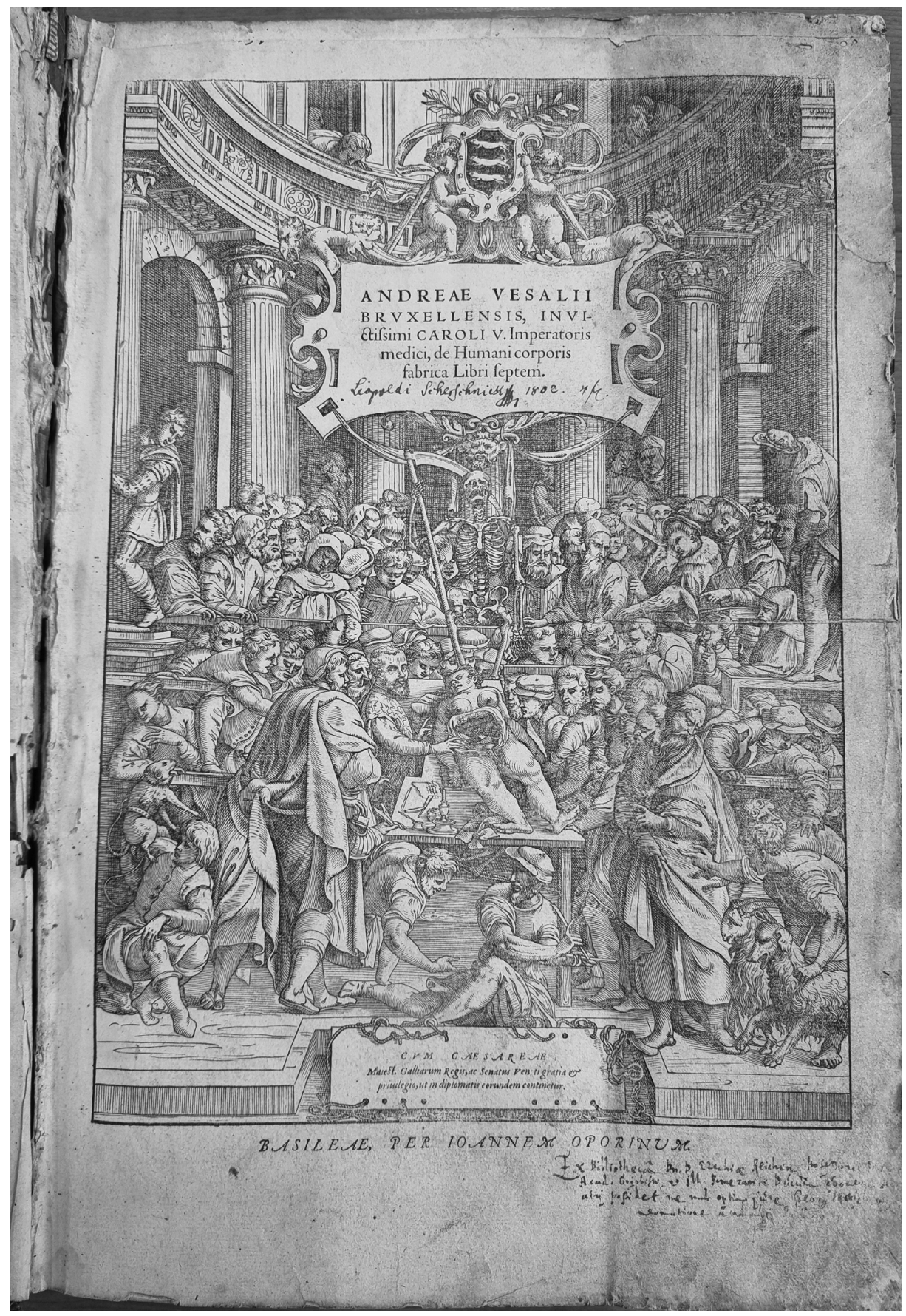

Il. 1. Andreas Vesalius, De humani corporis fabrica..., Basileae 1555; Cieszyn, Książnica Cieszyńska, sygn. SZ K I 01; karta tytułowa; fot. K. Nierzwicki 


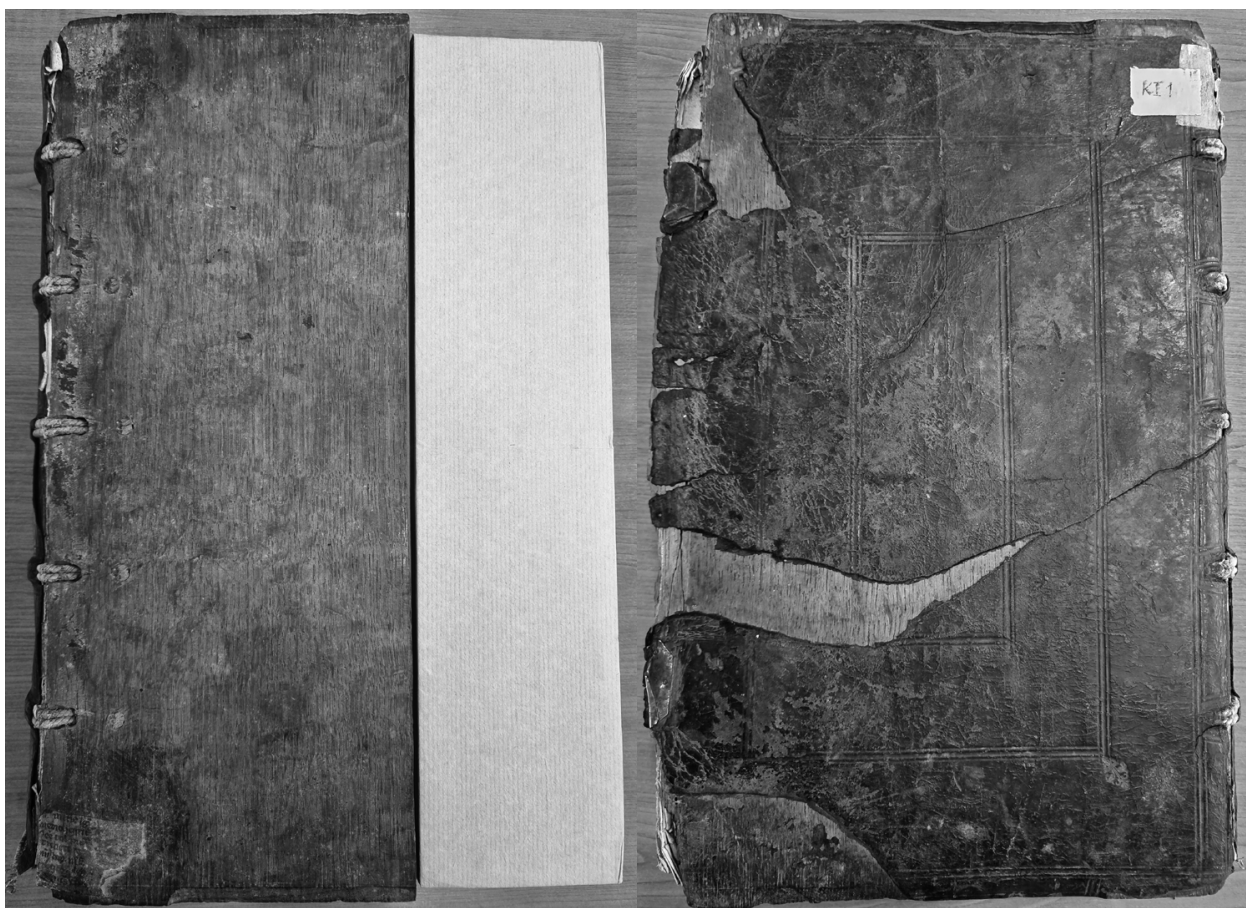

I1. 2. Andreas Vesalius, De humani corporis fabrica..., Basileae 1555; Cieszyn, Książnica Cieszyńska, sygn. SZ K I 01; górna okładzina woluminu; fot. K. Nierzwicki
I1. 3. Andreas Vesalius, De humani corporis fabrica..., Basileae 1555; Cieszyn, Książnica Cieszyńska, sygn. SZ K I 01; dolna okładzina woluminu; fot. K. Nierzwicki

Kompletny, choć pozbawiony części górnej okładziny i fragmentu jej karty ochronnej, egzemplarz ${ }^{5}$, zanim trafił do wspomnianej biblioteki, należał do co najmniej trzech znanych nam z imienia i nazwiska osób. Według wszelkiego prawdopodobieństwa pierwotnym posiadaczem omawianego tomu był Ezechias Reich (Reiche, Reichen), profesor medycyny i dwukrotny rektor uniwersytetu w Greifswaldzie, a od 1560 roku także książęcy lekarz na dworze w Wołogoszczy (Wolgast). Później wolumin znalazł się w rękach jego syna — prawnika Georga — by wreszcie na początku XIX wieku trafić do zbiorów uczonego i społecznika cieszyńskiego, księdza Leopolda Jana Szersznika. Dokumentację wspomnianej drogi woluminu stanowią trzy zapiski proweniencyjne przetrwałe na stronie tytułowej i fragmentarycznie zachowanej (oddartej) karcie ochronnej górnej okładziny egzemplarza.

także między innymi Bieńkowska, 1998, s. 138-150; Heinrich, 2004; Kudélka, 1957; Peters, 2000, s. [449]-459; Spyra, Chromik, 2014; Sztuchlik, Picha, 2002, s. 165-176; Zwiercan, 2003.

${ }^{5}$ Stan zachowania woluminu zostanie szczegółowo omówiony w drugiej części artykułu. 
Najstarsza z nich, niestety w części nieczytelna, nakreślona została najpewniej w końcu XVI wieku i umieszczono ją w dolnym prawym rogu karty tytułowej w brzmieniu:

Ex Bibliotheca Dn. D. Ezechiae Reichen Professoris Medic[inae] [...] Acad[emiae] Griphisw[aldensis] et ill[ustrissimorum] Pomeraniae Ducum phisicus (?) [...] utri[us] possidet me nunc optimo jure Georg [...] donatione [...] L. C. p.

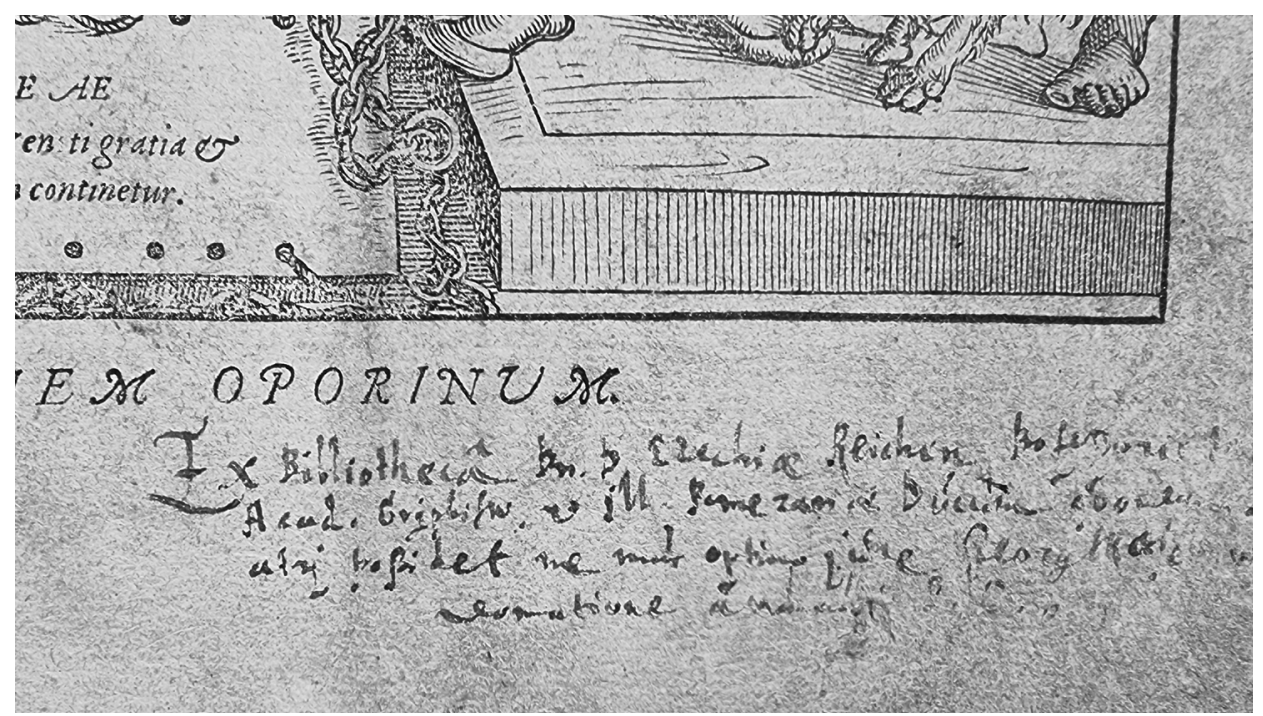

Il. 4. Andreas Vesalius, De humani corporis fabrica ..., Basileae 1555; Cieszyn, Książnica Cieszyńska, sygn. SZ K I 01; karta tytułowa, zapiska proweniencyjna poświadczająca obecność dzieła w zbiorach Ezechiasa i Georga Reichów; fot. K. Nierzwicki

To dowodzi obecności wesaliańskiego podręcznika w księgozbiorach wspomnianych już Ezechiasa Reicha i jego syna Georga. Notka ta znalazła się tam nieprzypadkowo. Członkowie rodziny Reichów, zajmujący szereg eksponowanych stanowisk w wielu miastach szesnastowiecznej Europy, należeli do elit społecznych i intelektualnych swoich czasów. Książka była zatem stale obecna w ich życiu prywatnym, społecznym, ale przede wszystkim zawodowym.

Pierwszy udokumentowany właściciel woluminu, Ezechias Reich, wywodził się właśnie z takiego domu, chociaż jeszcze jego dziadek ze strony ojca pochodził z ubogiego chłopstwa gospodarującego w okolicach Żagania na Śląsku. Ezechias wraz ze swym młodszym bratem Josiasem byli jedynymi znanymi nam dziećmi urodzonego w 1495 roku w Żaganiu przyszłego pastora Georga Reicha (Reichego) ${ }^{6}$. Postać dobrze wykształconego i ustosunkowanego seniora rodu, któ-

${ }^{6}$ Najnowsza literatura dotycząca Georga Reicha zob.: Jügelt, 1995, s. 103-114; Jügelt, 1999, s. 193-195; Jügelt, 2014, s. 40-52. Zob. także: Koppmann, 1890, s. 51-52; Krause, 1888, s. 651-652. Data urodzenia G. Reicha nie jest znana, ale źródła podają dokładną datę jego śmierci (1565) z in- 
ry bez wątpienia wywarł ogromny wpływ na wybór drogi życiowej swych synów, warta jest nieco bliższego poznania. Tym bardziej, że to właśnie za sprawą ojca właściciela pokaźnego i do dziś zachowanego w znacznej części księgozbioru obaj bracia mieli szansę dorastania w otoczeniu książek, co prawdopodobnie nie pozostało bez wpływu na późniejsze zainteresowania w tym obszarze starszego z nich - Ezechiasa. Co zatem wiemy o nim dzisiaj? Georg Reich (dla odróżnienia go od jego wnuka nazwijmy go starszym) od 1524 roku studiował na uniwersytecie w Wittenberdze, będąc uczniem Marcina Lutra, Filipa Melanchtona i Johannesa Bugenhagena (Foerstemann, 1841, s. 122; Jügelt, 2014, s. 42; Lange, 2014, s. 41) 7 . Pięć lat później spotykamy go w Królewcu Pruskim (Königsberg in Preußen), gdzie od 1529 roku pełnił posługę diakona w tamtejszej katedrze. Nie znamy zbyt wielu szczegółów jego pobytu w tym mieście. Wiemy jedynie, że niedługo potem, w 1536 roku — jak czytamy w kilku publikacjach — został uwięziony z powodu wygłoszenia pełnego niepochlebnych słów kazania na pogrzebie Friedricha von Heydecka, krzewiciela schwenckfeldiańskiego nurtu reformacji w Prusach, doradcy i bliskiego współpracownika księcia Albrechta (Besch, 1897, s. 529, 531; Jügelt, 2014, s. 42; Lange, 2014, s. 41; Lilienthal, 1725, s. 213; Rotermund, 1819, szp. 1598) ${ }^{8}$. Z końcem 1547 roku Reich z powodu niskich zarobków (Jügelt, 2014, s. 42) ${ }^{9}$ opuścił Królewiec i przez trzy kolejne lata przebywał w Tylży (obecnie Sowieck na terenie obwodu kaliningradzkiego), gdzie 15 stycznia 1548 roku został pastorem kościoła miejskiego (Tschackert, 1890, s. 417). W okresie tak zwanego sporu osiandryjskiego (Osianderstreit) stanął po stronie przeciwników kontrowersyjnego teologa luterańskiego Andreasa Osiandra (1498-1552), w wyniku czego w 1551 roku wraz z żoną i synami opuścił Prusy Książęce ${ }^{10}$ i udał się do Meklemburgii. W maju tego roku został najpierw kaznodzieją w Biestowie (Biestow) koło Rostocku, zaś 11 listopada 1554 roku książę Meklemburgii Johann Albrecht I mianował go proboszczem w kościele św. Mikołaja, jednej z głównych świątyń hanzeatyckiego miasta Rostock (Etwas von gelehrten..., 1739, s. 607). W 1551 roku Georg Reich immatrykulował się na miejscowym uniwersytecie, gdzie 28 lipca uzyskał tytuł magistra artium (Hofmeister, 1891, s. 121) ${ }^{11}$. Z własnych funduszy

formacją, że zmarł on w siedemdziesiątym roku swego życia; zob. Etwas von gelehrten..., 1740, s. 278-279; Krabbe, 1870, s. 227.

7 W albumie uniwersyteckim Foerstemanna (1841) został zapisany jako: „Georgius Reicher Saganen ex Silesia".

${ }^{8}$ Z kolei Gabriela Wąs (2011, s. 315-316) przytacza ten fakt z życiorysu G. Reicha, ale twierdzi przy tym, że nic nie wiadomo o ukaraniu go przez księcia Albrechta.

9 O G. Reichu zob. także Gebser, 1835, s. 332, 366 (według tego autora Reich zarabiał przez pierwsze dziesięć lat 40 marek, później 50).

${ }^{10}$ Informacji tej nie podaje współczesny biograf G. Reicha Karl-Heinz Jügelt (2014, s. 42-43).

11 Zob. też cyfrowa kopia rękopisu: „Matricula Academiae Rostochiensis: [1419-1760]”, Universitätsarchiv Rostock, sygn. 1.8 Matrikelbücher, http://purl.uni-rostock.de/rosdok/ppn63866263X http://purl.uni-rostock.de/rosdok/ppn63866263X (dostęp: 10.06.2021). 


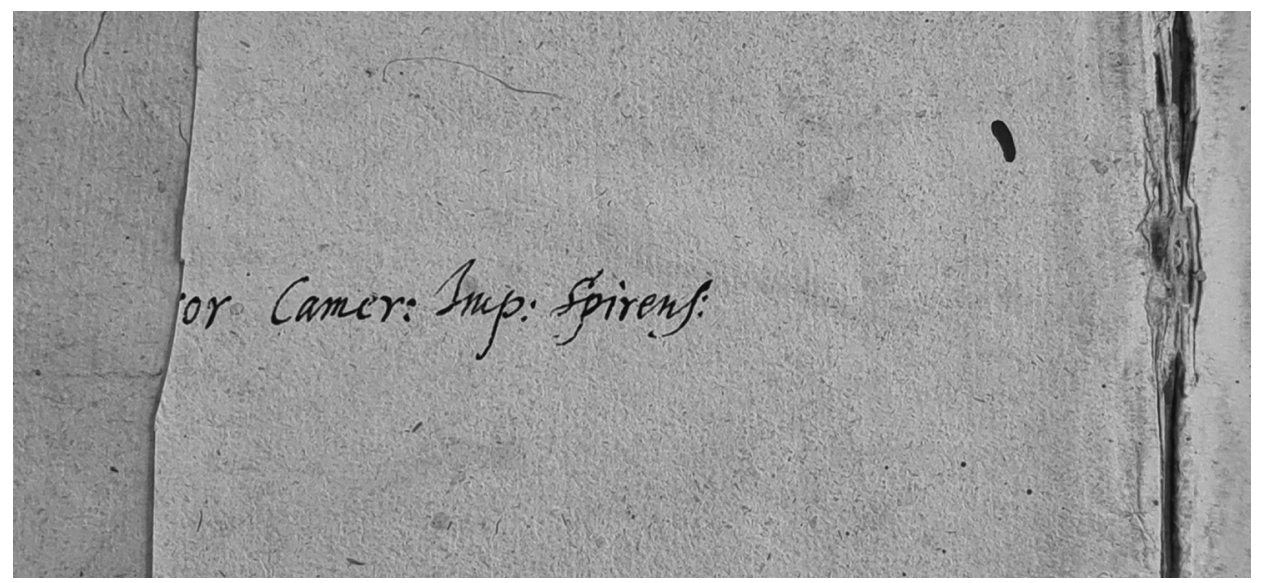

Il. 5. Andreas Vesalius, De humani corporis fabrica ..., Basileae 1555; Cieszyn, Książnica Cieszyńska, sygn. SZ K I 01; fragment karty ochronnej górnej okładziny z zapiską poświadczającą obecność dzieła w zbiorach Georga Reicha mł., asesora sądu Rzeszy w Spirze; fot. K. Nierzwicki

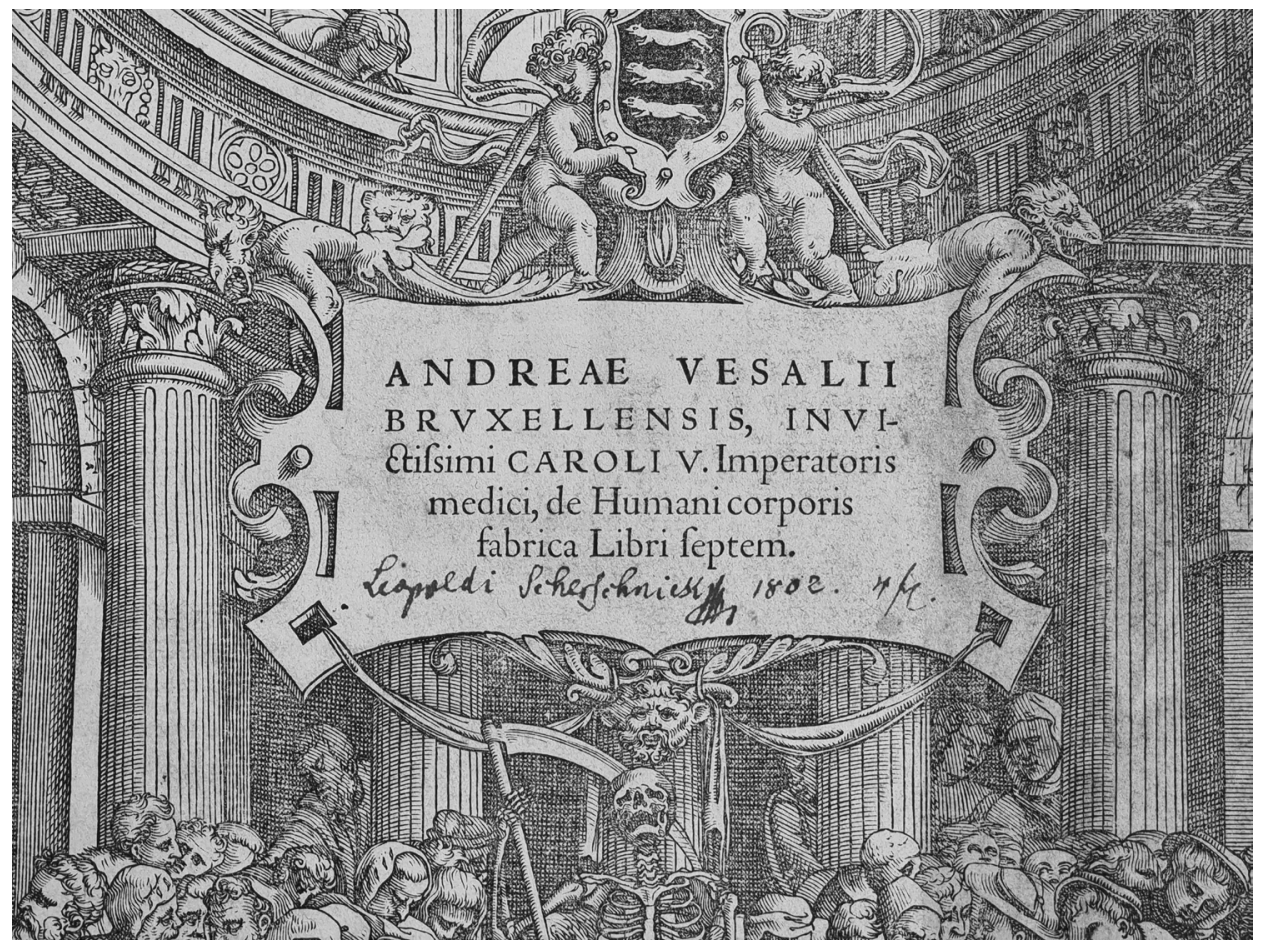

I1. 6. Andreas Vesalius, De humani corporis fabrica..., Basileae 1555; Cieszyn, Książnica Cieszyńska, sygn. SZ K I 01; karta tytułowa, zapiska proweniencyjna poświadczająca obecność dzieła w kolekcji Leopolda Jana Szersznika; fot. K. Nierzwicki 
odbudował bursę studencką „Regentie Rubri Leonis”, a także przyczynił się do wzbogacenia jej biblioteki, co zostanie szerzej omówione w dalszej części tekstu. Georg Reich starszy zmarł 2 października 1565 roku w Rostocku w wieku 70 lat w wyniku szalejącej w tym mieście dżumy (Etwas von gelehrten..., 1740, s. 278-281; Krause, 1888, s. 651-652; Rottermund, 1819, szp. 1598). Jego żoną, a zarazem matką Ezechiasa, była pochodząca prawdopodobnie z gdańskiej rodziny patrycjuszy Gertrud von der Becke (Beke), urodzona w 1493 roku, zmarła 6 kwietnia 1571 roku (Jügelt, 2014, s. 43; Thümmel, 2002, s. 78-79) i pochowana w kościele św. Mikołaja w Greifswaldzie pod wspólnym z synem Ezechiasem epitafium (Herold, Magin, 2012).

Główna postać niniejszego artykułu, starszy z synów Georga, Ezechias Reich, urodził się w Królewcu w 1532 roku. Niemal na pewno początkowe lata swej edukacji odbył w rodzinnym mieście, zapisany najpierw do założonego w październiku 1541 roku tak zwanego studium particulare, by trzy lata później wraz z pozostałymi 184 uczniami tej placówki wejść en bloc w skład pierwszego rocznika studentów erygowanego wtedy uniwersytetu. Potwierdzają to matrykuły uniwersyteckie wymieniające Ezechiasa oraz jego młodszego brata Josiasa (1535-1568) na początku drugiej setki pierwszego rocznika studentów Albertyny (Erler, 1910, s. 2; Serczyk, 1994, s. 19; Skrobacki, 1969, s. 18). Trudno powiedzieć, kiedy dokładnie Ezechias rozpoczął edukację w królewieckim partykularzu. Przypuszczalnie stało się to niedługo po jego utworzeniu, być może jeszcze w 1541 lub na początku 1542 roku, wiadomo bowiem, że pierwszy rektor Albertyny, Georg Sabinus, immatrykulując na uniwersytecie wspomnianych 184 uczniów, uczynił to jedynie w stosunku do starszych roczników (Erler, 1910, s. 2). W grupie tej znalazł się Ezechias — wówczas dwunastolatek. Królewieckie studium particulare było też pierwszym miejscem, gdzie młody Reich zetknął się z naukami medycznymi, których podstawy — w świetle aktu fundacyjnego szkoły — stanowiły, obok nauki greki, łaciny, języka hebrajskiego oraz początków teologii i prawa, jeden z przedmiotów nauczania (Skrobacki, 1969, s. 18). Bez wątpienia przyszły rektor uniwersytetu w Greifswaldzie pierwsze kroki ku profesji medyka stawiał u boku wybitnego uczonego lekarza i humanisty - Johannesa Placotomusa (właściwie Johanna Brettschneidera, 1514-1577) — poznanego być może jeszcze w szkole średniej, którą przyszły mentor interesującej nas postaci krótko zarządzał (Armstedt, 1911, s. 59), zanim został powołany na stanowisko profesora medycyny na Albertynie (Schwarz, 2001, s. 495). Ezechias pogłębiał swe zainteresowania, uczęszczając na wykłady Placotomusa już podczas studiów uniwersyteckich (Braun i in., 1956, s. 469). Królewieckie związki Reicha z Placotomusem legły zapewne u podstaw błędnego poglądu, jakoby Ezechias był również uczniem gdańskiego gimnazjum (Scheffel, 1756, s. 23), w którym wybitny medyk nauczał po opuszczeniu Królewca. Patrząc na historię tej placówki, założonej w 1558 roku (Sokół, 1960, s. 68-70; Siek, Szarszewski, 2015, s. 25-27), 
nie wydaje się to możliwe, ponieważ Reich w chwili jej powstania już od dwóch lat posiadał stopień naukowy doktora medycyny, a rok później otrzymał stanowisko profesora na uniwersytecie w Greifswaldzie. Niezależnie od tych wątpliwości mamy pewność, że Ezechias zamiłowanie do medycyny wyniósł właśnie z Królewca. Obok Placotomusa w kręgu uczonych medyków królewieckich w okresie edukacji Reicha znajdował się także nie mniej znany lekarz, a z czasem profesor oraz rektor Albertyny, wielki miłośnik i kolekcjoner książek — wrocławianin Andreas Aurifaber (Goldschmid, 1513-1559). Również i jego postać mogła wpłynąć na kształtowanie młodego adepta medycyny, któremu imponowali wybitni i doskonale wykształceni na zachodnich uniwersytetach medycy. Jak długo Ezechias pozostawał na tamtejszym uniwersytecie, nie wiadomo. Przypuszczalnie rodzina wraz z ojcem Georgiem przeniosła się z końcem 1547 roku do Tylży, choć nie wiemy, czy synowie wówczas przerwali naukę uniwersytecką. Tak czy inaczej, to właśnie w murach Albertyny przyszły medyk miał szansę po raz pierwszy zetknąc się z wielkim anatomicznym dziełem Andreasa Vesaliusa De humani corporis fabrica, którego editio princeps z 1543 roku znajdowało się wówczas na pulpicie służącej społeczności akademickiej Biblioteki Zamkowej. Trafiło tam prawdopodobnie w niedługim czasie po wydrukowaniu, odnotowane w pierwotnym jej katalogu, sporządzonym w latach $1540-1548$ przez bibliotekarza Felixa Königa (Polyphemus) (Kuhnert, 1926, s. 29; Nierzwicki, 2021b, s. 37, 45; Tondel, 1992, s. 95, 111).

Jak już wspomniano, rodzina Reichów - w następstwie toczącego się sporu zwolenników i przeciwników poglądów Andreasa Osiandra - opuściła Prusy przypuszczalnie w roku 1551. Nie byli oni jedyni. Z Królewca odeszło wówczas wielu uczonych i nauczycieli, w tym także Johannes Placotomus, który udał się do Gdańska (Sokół, 1960, s. 38). Reichowie natomiast przenieśli się do Meklemburgii. Rok później spotykamy Ezechiasa na kolejnym uniwersytecie, tym razem w Rostocku. Z tamtejszych matrykuł uniwersyteckich dowiadujemy się, że immatrykulował się on w październiku 1551 roku. Do jego nazwiska później dopisano doctor medicinae (Hofmeister, 1891, s. 121). Na uniwersytet wstąpił on wraz z bratem Josiasem, późniejszym licencjatem teologii (1564), a po śmierci ojca pastorem w kościele św. Mikołaja w Rostocku (Etwas von gelehrten..., 1740, s. 281-283). Obaj określeni są jako bracia wywodzący się ze Śląska (,fratres Silesii”), co było następstwem dolnośląskiego pochodzenia ich ojca (urodzonego w Żaganiu). Również i w tym wypadku nie wiemy, jak długo młody Reich pozostawał na uczelni. Niespełna trzy lata później odnajdujemy go w mekce protestanckiej edukacji - na uniwersytecie w Wittenberdze, gdzie immatrykulował się 23 maja 1554 roku $^{12}$ Następnie Ezechias udał się w celu dalszej edukacji do Włoch, na jeden z najlep-

12 Universitäts- und Landesbibliothek Sachsen-Anhalt, „Album Academiae Vitebergensis”, rkps. sygn. Yo (2), k. 19v. (wpis pod datą 23.05.1554 „Ezechias Reich Regiomontanus“). Zob. także 
szych uniwersytetów renesansowej Europy, słynący z nowoczesnego nauczania medycyny - Uniwersytet Padewski. W 1555 roku wzmiankowany jest na tej uczelni jako prokurator „Natio Germana Artistarum”, zaś rok później, w sierpniu 1556 roku, uzyskuje tam doktorat (Favro, 1911, s. 13, 15).

Według niektórych badaczy jeszcze przed otrzymaniem stopnia doktora medycyny Ezechias kontynuował edukację w Bolonii, Neapolu i Rzymie (między innymi Scheffel, 1756, s. 23) ${ }^{13}$, a dopiero po tych peregrynacjach powrócił do Padwy, by zwieńczyć studia doktoratem (Scheffel, 1756, s. 23). W mieście tym jego nauczycielami byli wybitni lekarze włoscy: Gabrielle Falloppio (1523-1562), Vittore Trincavelli (1496-1568) oraz Girolamo Capivaccio (1523-1589) (Anselmino, 1906, s. 107; Kosegarten, 1857, s. 203).

W 1559 roku Reich otrzymał posadę profesora medycyny na uniwersytecie w Greifswaldzie, gdzie wykładał między innymi Fizykę Melanchtona (Balthasar, 1725, s. 441; Kosegarten, 1857, s. 213). Dwukrotnie, w 1561 i 1572 roku, był rektorem uniwersytetu (Friedländer i in., 1893, s. 268, 306). Wygłosił kilka publicznych przemówień i wziął udział w różnych dyskusjach, w tym w „De febre pestilentiali” na okoliczność wybuchu epidemii w 1564 roku. W listopadzie 1559 roku został osobistym lekarzem nadwornym (Buchhester, 2015, s. 190) współrządzących książąt pomorskich Jana Fryderyka (Johann Friedrich, 1542-1600) i Bogusława XIII (Bogislaw XIII, 1544-1606), a następnie Ernesta Ludwika (Ernst Ludwig, 1545-1592) w Wołogoszczy. Był żonaty z Magdaleną Schwarz, córką rostockiego przedsiębiorcy, z którą miał troje dzieci - syna Georga oraz dwie córki, Gertrudę i Magdalenę (Scheffel, 1756, s. 29). Gertruda wyszła za mąż za prawnika, rektora uniwersytetu w Greifswaldzie, Johannesa Oestena (zm. 1592) (Thümmel, 2002, s. 86-87), zaś Magdalena poślubiła rajcę miejskiego, Christopha Corswanta (zm. 1598) (Balthasar, Dinnies, Gesterding, 1868, s. 379-380; Gesterding, 1829, s. 116).

Ezechias w ciągu swego niedługiego, bo zaledwie czterdziestoletniego życia, zawarł wiele interesujących znajomości i przyjaźni, choćby z wybitnym uczonym szwajcarskim, bibliografem, bibliofilem, lekarzem i przyrodnikiem, Konradem Gesnerem (1516-1565), któremu 10 września 1558 roku wpisał się do sztambucha (Album amicorum) (Durling, 1965, s. 145; Urban, 2000, s. 217). W czasie swego pobytu w Rostocku w 1555 roku poznał również peregrynującego wówczas po Rzeczypospolitej i Meklemburgii wybitnego francuskiego dyplomatę i reformatora religijnego, Huberta Langueta (1518-1581), do którego napisał przynajmniej je-

edycję tego rękopisu: „Album Academiae Vitebergensis...”, 1894, s. 293. Por. Freytag, 1903, s. 51 (gdzie błędnie podano datę 13 maja).

13 Jego nazwiska nie rejestrują jednak akta nacji niemieckiej uniwersytetu bolońskiego, por. Friedlaenser, Malagola, 1887. Wzmiankowani są tam jedynie w 1560 roku Georg Reich i Petrus Reich, obaj jednak niemający nic wspólnego z greifswaldzką rodziną Reichów, zob. s. 284 i 337. Por. też Knod, 1899, s. 437. 


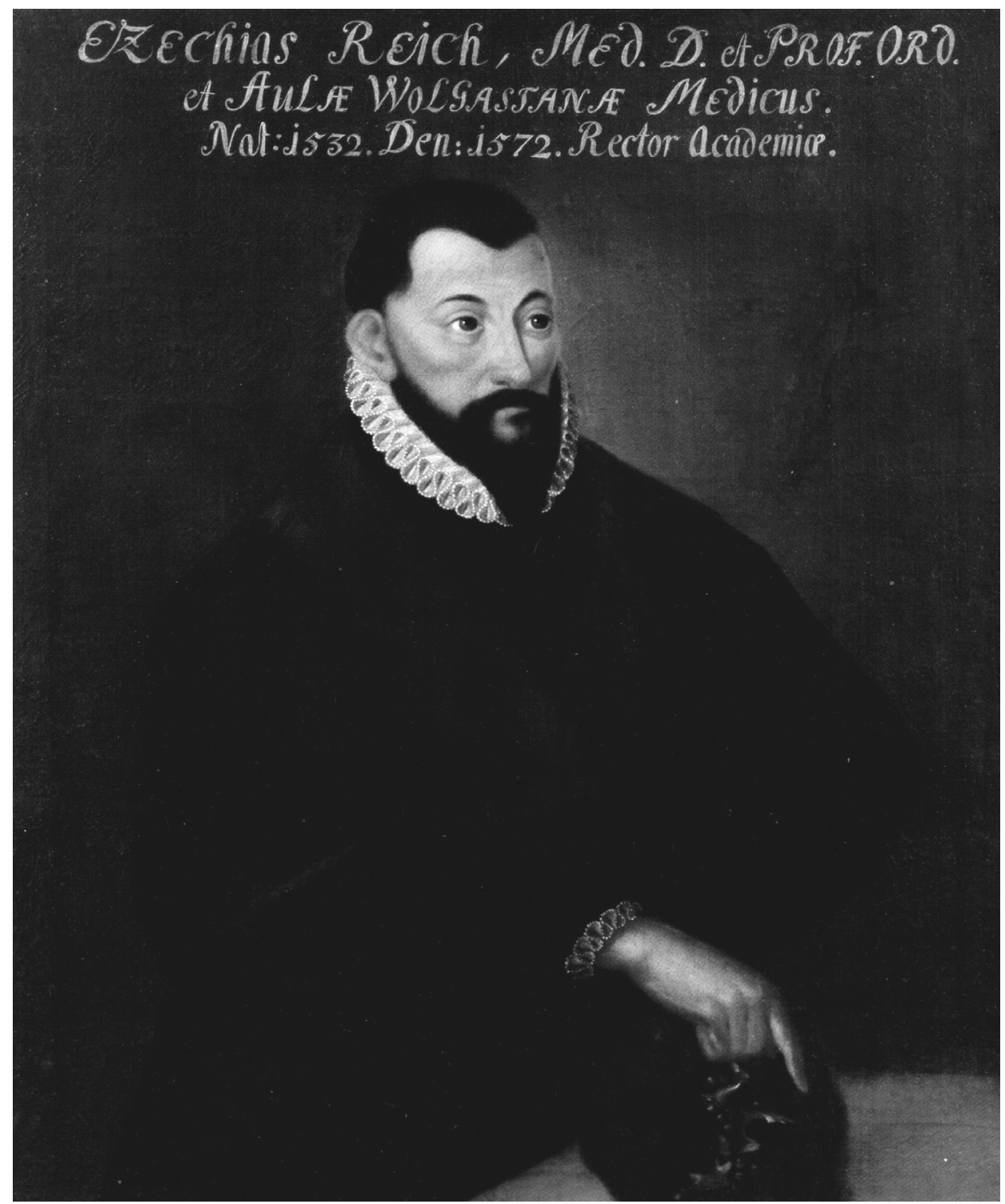

I1. 7. Portret Ezechiasa Reicha, Johann Pieron;

https://de.wikipedia.org/wiki/Ezechias_Reich\#/media/Datei:EzechiasReich.JPG 
den - zachowany w Bibliothèque nationale de France w Paryżu — list (Nicollier-De Weck, 1995, s. 40) ${ }^{14}$. Zmarł 20 grudnia 1572 roku, w czasie swej drugiej kadencji rektorskiej, i został pochowany w kościele św. Mikołaja w Greifswaldzie, zaś jego epitafium niegdyś znajdowało się w katedrze greifswaldzkiej pod organami (Braun i in., 1956, s. 275; Ewert, G., Ewert, R., 2013, s. 30; Herold, Magin, 2012; Magin, 2010, s. 104-106).

Jak już zaznaczono, zamiłowanie do książek Ezechias bez wątpienia wyniósł z domu rodzinnego. Jego ojciec Georg jako pastor w kościele św. Mikołaja w Rostocku aktywnie włączył się w życie religijne i intelektualne miasta. Posiadał on przy tym znaczący księgozbiór, głównie o charakterze teologicznym, który w sporej części niemal sto lat po jego śmierci trafił do zasobów uniwersytetu w Rostocku, stając się de facto podstawą jego biblioteki (Corsten i in., 1996, s. 123; Jügelt, 2014, s. 49; Scheffel, 1756, s. 22). Spis owych zbiorów, sporządzony w 1657 roku, rejestrował około 130 woluminów zawierających ponad 700 tytułów dzieł, w tym wiele pierwodruków pism Lutra. Do dzisiaj w Bibliotece Uniwersyteckiej w Rostocku zidentyfikowano prawie cały ten zasób. 62 tomy in quarto obejmują ogromną liczbę ponad 500 dawnych reformacyjnych druków ulotnych. Większość z nich pochodzi z pierwszej połowy XVI wieku. Udało się również zidentyfikować cztery inkunabuły (Krüger, 2003, s. 15, 91-92 (poz. A 14), 283 (poz. J 9)). Oprócz dzieł M. Lutra w zbiorach Georga Reicha starszego dominują prace F. Melanchtona, Johannesa Bugenhagena, Johanna Wiganda, Johanna Briessmanna, Andreasa Osiandra i wielu innych luminarzy teologii reformacyjnej. Obok tego w księgozbiorze Reicha spotykamy także dzieła wybitnych humanistów: Erazma z Rotterdamu, Heinricha Bebela (Henricusa Bebeliusa), Giovanniego Pico della Mirandoli oraz Thomasa More'a (Morusa). Z autorów starożytnych posiadał Reich pisma Cycerona i Seneki. W jego zbiorach znajdowały się również podręczniki gramatyki hebrajskiej, jak choćby Grammatica hebraica absolutissima Eliae Levitae Germani w tłumaczeniu Sebastiana Münstera, wydrukowana w Bazylei u Johanna Frobena w 1525 roku $^{15}$. Co ważne, pastor gromadził książki już podczas pobytu w Królewcu, a więc w czasie, kiedy jego synowie byli jeszcze dziećmi, a on sam posługiwał jako kapelan w katedrze w Knipawie (Kneiphof). Świadczą o tym zapisy na wielu tomach pochodzących z jego księgozbioru w brzmieniu „Sum Georgij Reichij Sacellani knibhouiensis” (Corsten i in., 1996, s. 123; Jügelt, 2014, s. 49). Kolekcja pastora Reicha — jak już wspomniano - w drugiej połowie XVII wieku została włączona do zasobów

${ }^{14}$ Zob. również portal Frühneuzeitliche Ärztebriefe des deutschsprachigen Raums (15001700), przygotowany przez Bayerische Akademie der Wissenschaften. Institut für Geschichte der Medizin, www.aerztebriefe.de/id/00051001 (dostęp: 12.06.2021).

15 O dziele tym zob. VD16, E 1001, wersja online: http://gateway-bayern.de/VD16+E+1001 (dostęp: 11.06.2021) oraz Lange, 2018, s. 24, 466-469. 
Biblioteki Uniwersyteckiej w Rostocku, która swe początki zawdzięcza profesorowi poezji, historykowi i teologowi Nathanowi Chytraeusowi (Chyträusowi, 1543-1598). Zanim do tego doszło, omawiany księgozbiór znalazł się w rękach starszego brata wspomnianego Nathana — Davida (1530 - 1600), luterańskiego teologa i historyka, również profesora uniwersytetu w Rostocku, a zarazem przyjaciela rodziny Reichów, który przeznaczył księgozbiór do przekazania wspomnianej wcześniej, odbudowanej przez Georga, bursie pod Czerwonym Lwem (Chyträus, 1599, s. 558; Jügelt, 2014, s. 49-50). Trudno powiedzieć, czy był to cały zasób biblioteczki Georga, czy może jakąś jej część odziedziczyli synowie. W chwili śmierci ojca Ezechias przebywał od kilku lat w Greifswaldzie, pracując jako profesor medycyny na tamtejszym uniwersytecie, zaś Josias - o czym już wspomniano - objął po rodzicu funkcję pastora w kościele św. Mikołaja. Jeśli przyjmiemy, że księgozbiór Georga miał charakter głównie teologiczno-reformacyjny, to raczej nietrudno założyć, że mógł on choćby częściowo zainteresować jego młodszego syna, który parał się tą samą profesją i mieszkał w tym samym mieście. Jeśli znajdowała się w nim literatura $\mathrm{z}$ zakresu medycyny, to jest wielce prawdopodobne, że odziedziczył ją związany z tą nauką Ezechias. Nie wydaje się jednak, aby do tego hipotetycznego spadku należał omawiany tom Fabricae Vesaliusa. Wspomniana zapiska proweniencyjna, którą sporządzono bez wątpienia po śmierci Ezechiasa, na to nie wskazuje. Bardziej prawdopodobne wydaje się, że starszy syn Georga zakupił to cenne dzieło podczas swych studiów we Włoszech. Mogło się to wydarzyć w Padwie, gdzie postać Andreasa Vesaliusa i jego dorobek były powszechnie znane i cenione, zwłaszcza że Ezechias przebywał tam w chwili, kiedy ukazała się druga edycja tego dzieła, która zatem musiała być dostępna na tamtejszym rynku księgarskim. Zastanowienie budzi jedynie brak jakiejkolwiek sporządzonej przez nabywcę tego cennego egzemplarza notki potwierdzającej ten przypuszczalny zakup. Możliwe jednak, że znajdowała się ona na wspomnianym wcześniej oderwanym fragmencie karty ochronnej górnej okładziny tomu.

Zamknąwszy wątek charakterystyki postaci pierwszego właściciela omawianego druku, pozostaje nam przynajmniej próba udzielenia odpowiedzi na pytanie o jego ewentualne zainteresowania bibliofilskie czy też o posiadany przez niego księgozbiór. Chociaż możemy dogłębnie przeanalizować zasób biblioteki Georga Reicha starszego, która zachowała się w sporej części w Rostocku, to niestety niewiele możemy powiedzieć o księgozbiorze, czy też szerzej o zamiłowaniu do książki, samego Ezechiasa. Zapis proweniencyjny na omawianym kodeksie, rozpoczynający się od słów „Ex Bibliotheca [...] Ezechiae Reichen [...]”, pozwala nam mniemać, że uczony medyk dysponował przynajmniej jakimś podręcznym księgozbiorem, zaś wolumin Vesaliusa nie był jedyną posiadaną przez niego książką. Trudno sobie wyobrazić, aby mogło być inaczej. Ezechias zdobył solidne wy- 
kształcenie na kilku uniwersytetach (Królewiec, Rostock, Wittenberga, Padwa), gdzie kontakt z książką, zarówno tą przechowywaną w uczelnianych bibliotekach, jak i dostępną na rynku księgarskim, był oczywisty. Nasze graniczące z pewnością przekonanie umocnimy, kiedy dodamy do tego wyniesioną przez Ezechiasa $\mathrm{z}$ domu rodzinnego potrzebę otaczania się książkami, jaką przejawiał jego ojciec, a także odpowiedzialny i wymagający pomocy naukowych fach, który przyszło mu wykonywać w dorosłym życiu. Zawód lekarza, do tego dworskiego, którym parał się Ezechias od 1559 roku, a także podjęta od tego roku praca profesora uniwersytetu w Greifswaldzie, a później też jego rektora, nie mogły obyć się bez książek. Literatura bibliologiczna obfituje wszak w wiele informacji o profesorskich księgozbiorach ${ }^{16}$, a zatem nie inaczej musiało być w przypadku Ezechiasa Reicha. Trudno jednak pokusić się o próbę charakterystyki, czy tym bardziej ocenę wielkości, tego hipotetycznego księgozbioru. Można jedynie przypuszczać, że była to przynajmniej podstawowa kolekcja praktykującego lekarza, a zarazem uczonego i dydaktyka, zaś obecność w niej wielkiego, a przy tym kosztownego, dzieła Vesaliusa dowodzi, że celem naszego bohatera było gromadzenie najważniejszej bieżącej literatury naukowej, bez szczędzenia środków pieniężnych na nią.

Omawiany egzemplarz po śmierci Ezechiasa pozostał przypuszczalnie w rękach rodziny, by w pewnym momencie — jak już wspomniano — zasilić zbiory jego syna Georga, urodzonego w Greifswaldzie w 1568 roku i zmarłego najprawdopodobniej w Spirze pomiędzy latami 1616 a 1620. Wniosek taki można wysnuć z lektury dalszej części wspomnianej wyżej zapiski proweniencyjnej: ,„[...] posidet me nunc optimo jure Georg [...]". Niestety ów fragment tekstu jest mocno wytarty, a przez to prawie zupełnie nieczytelny, chociaż niemal pewne jest, że po słowach optimo jure znajdują się informacje o kolejnym posiadaczu tej księgi, czyli właśnie Georgu młodszym.

Zidentyfikowanie tej postaci byłoby zupełnie niemożliwe, gdyby nie kolejna, nieco młodsza od poprzedniej, zapiska znajdująca się tym razem na karcie ochronnej górnej okładziny. Zachowała się ona niestety nie w pełni, oddarto ją bowiem mniej więcej w połowie wraz ze wspomnianą kartą. Zapis ten, sporządzony po 1593 roku, brzmi: „[...]or Camer. Imp. Spirens.”, co najpewniej można rozwiązać jako: „[Assess]or Camer[ae] Imp[erialis] Spirens[is]”. Wskazuje on na osobę sprawującą funkcję asesora sądu kameralnego Rzeszy (Reichskammergericht), najwyższej instancji sądownictwa I Rzeszy w epoce nowożytnej, który działał w latach 1527-1689 w Spirze. Stanowisko to pełnił od 1593 roku właśnie syn Ezechiasa Reicha — Georg (Gruterus, 1612, s. 764 ${ }^{17}$ ). Związek logiczny między informacjami

16 Jeśli sięgnąć tylko do literatury polskiej, to warto przypomnieć choćby monumentalną pracę o bibliotekach profesorów krakowskich autorstwa Wacławy Szelińskiej (1966).

$17 \mathrm{~W}$ dziele tym znajduje się wierszowany tekst poświęcony jego osobie: „Georgio Reichio. I. V. D. assessori Camerae Imperialis. / Clarus avus, clarus genitor, clarissimus ipse es, / Illustrat 
pochodzących ze wspomnianych zapisek pozwala na wysnucie niemal pewnego wniosku, że omawiany egzemplarz przeszedł z ojca na syna, zaś zawarte w starszej notce wzmiankowane już sformułowanie „optimo jure” daje nam powód, by mniemać, że książka w zbiorach młodszego Reicha znalazła się w drodze prawnego dziedziczenia, być może w konsekwencji zapisu testamentalnego. Wydaje się to zresztą uzasadnione, bowiem w chwili śmierci Ezechiasa jego syn miał zaledwie cztery lata. Niewykluczone, że notatkę sporządził sam Georg Reich młodszy.

Wnuk i imiennik pochodzącego z Żagania pastora ${ }^{18}$ urodził się, jak już wspomniano, w 1568 roku w mieście, w którym Ezechias pracował zawodowo, czyli Greifswaldzie. Ojca — jak już wiemy — Georg stracił wcześnie, jeszcze w wieku dziecięcym. Edukację uniwersytecką zaczął on bardzo szybko, bowiem już jako dziesięciolatek — w 1578 roku znalazł się w gronie studentów miejscowego uniwersytetu. Pamięć o jego rodzicielu na greifswaldzkiej Alma Mater musiała być w tym okresie jeszcze bardzo żywa, skoro zapiska w matrykułach odnotowująca fakt wstąpienia Georga w progi uczelni brzmiała tak: „Georgius Reich, doctoris Ezechiae piae memoriae filius, gratis in memoriam parentis" (Friedländer E. i in., 1893, s. 315), zaś samemu uczniowi nie naliczono czesnego. Osiem lat później odnajdujemy go na uniwersytecie w Wittenberdze, gdzie immatrykulował się 15 maja 1586 roku wraz ze swym przyszłym szwagrem Christophem Corswantem (Album Academiae vitebergensis..., 1894, s. 337). W 1587 roku w tamtejszej oficynie Simona Gronenberga ukazały się jego Theses de usucapionibus et praescriptionibus - czterokartkowy druk prawniczy, będący jedną z trzech znanych nam publikacji autorstwa Georga Reicha ${ }^{19}$. W czerwcu 1589 roku Georga, ponownie razem z Corswantem, odnotowano w matrykułach uniwersytetu w Marburgu (Caesar C. I., 1879, s. 33), zaś w sierpniu 1590 roku spotykamy go na uczelni w Kolonii, gdzie wygłosił swoje kolejne tezy prawnicze - Theses de solutione et acceptilatione, rok później opublikowane w formie czterokartkowego druku w kolońskiej drukarni Johanna Waldorfa ${ }^{20}$. Czy Georg był tym samym

clarus te quoque luce soccer. / Saxo potens socerum, Themidos te Spira tribunal, / Grypsuvaldis patrem, sed Rosa clarat avum. / Nil nisi clara decent quoniam tua nomina Reichi, / Sit tibi cum nato clarus et ipse nepos. / Vos estis, dum fata sinunt, eritisque perenne, / Sidera clara solo, sidera clara polo".

18 Najszersze informacje odnoszące się do postaci Georga Reicha młodszego, zaczerpnięte z szeregu starszych publikacji, zamieszczono w zawierającym wiele danych biograficznych na temat obywateli Spiry przełomu XVI i XVII wieku portalu Thesaurus Personarum. Pfälzische Personengeschichte des 16. bis 18. Jahrhunderts, którego twórcą jest Hans-Helmut Görtz, https://www. thesaurus-personarum.de/reichskammergericht/\#182-223-r-assesoren-reichskammergericht-5f5f7cda0f664-p2 (dostęp: 15.05.2021).

19 Zob. Reich, 1587; VD16, ZV 25133, wersja online: http://gateway-bayern.de/VD16+ZV+ 25133 (dostęp: 10.06.2021).

20 Zob. Cronenburger, Reich, 1591; VD16 C 6018, wersja online: http://gateway-bayern.de/VD 16+C+6018 (dostęp: 10.06.2021). 
immatrykulowany na tamtejszym uniwersytecie — nie wiadomo. Nie wspominają o nim matrykuły kolońskie (zob. Nyassi, Wilkes, 1981). W tym samym roku 30 czerwca 1591 roku - wstąpił on w szeregi studentów kolejnej uczelni, tym razem w Heidelbergu, co w tym wypadku znalazło odzwierciedlenie w uniwersyteckich matrykułach (Toepke, 1886, s. 153; Petersdorff, 1887, s. 215). W 1593 roku w Wittenberdze ukazała się jego dysertacja Prima pars conclusionum repet. in cap. episcop. vel abbat. etc., wydrukowana w oficynie Zachariasa Lehmanna, $\mathrm{w}$ której to publikacji autor przedstawiony jest już jako doktor obojga praw ${ }^{21}$.

W tym samym roku Georg rozpoczął służbę jako asesor we wspomnianym Reichskammergericht — sądzie Rzeszy w Spirze — gdzie wzmiankowany jest kolejno w latach 1597, 1608, 1615 i 1616 (Ludolf, 1741, s. 398, 399, 401, 403, 411; Günther, 1608 22 ; Kamptz, 1802, s. $127^{23}$ ). Jego małżonką została rok później Justina Peifer (Pfeifer), jedna z czterech córek wybitnego prawnika, poety i publicysty Davida Peifera (Pfeifera; 1530-1602) (Kusche, 2005). Za sprawą tego związku młody Georg musiał wejść do rodziny o znaczącej pozycji społecznej, skoro z okazji ślubu, który odbył się w styczniu 1594 roku, jego teść został obdarowany przez księcia Fryderyka Wilhelma (Friedrich Wilhelm I. von Sachsen-Weimar, 15621602) drogocennym naczyniem do picia i beczką doskonałego wina reńskiego (Eisenhart, 1887, s. 321-324), zaś znakomity niemiecki prawnik, wydawca i poeta Nikolaus Reusner (1545-1602) skreślił na cześć młodej pary kilkunastowersowy łaciński epigram, który znalazł się w czwartym tomie zbioru jego prac Opera ${ }^{24}$. Oboje małżonkowie w okresie od 1593 do 1620 roku wymieniani są w metrykach parafialnych kościołów św. Jerzego i Predigerkirche (dominikańskiego) w Spirze jako rodzice chrzestni kilkanaściorga dzieci, przy czym w 1620 roku Justina wzmiankowana jest już jako wdowa (Görtz, 2018, s. 1172-1174) ${ }^{25}$. Można zatem przyjąć, że Georg Reich zmarł pomiędzy 1616 a 1620 rokiem. W swym mieście zyskał bez wątpienia szacunek i uznanie (być może także za sprawą ożenku z córką Peifera). Świadczy o tym nie tylko spora liczba podawanych przez niego do chrztu dzieci miejscowych patrycjuszy, ale także pojawianie się jego postaci w korespondencji wybitnych przedstawicieli środowiska naukowego, jak choćby

21 Zob. Reich, 1593; VD16, ZV 23056; wersja online: http://gateway-bayern.de/VD16+ZV +23056 (dostęp: 10.06.2021).

22 Brak numeracji stron, G. Reich występuje w dziale „Nomma [sic!] DD. Adressorum” pod literą $\mathrm{R}$.

23 Von Kamptz (1802) nie podaje daty zakończenia służby.

${ }^{24}$ Zob. Reusner, 1594, s. 515-516; VD 16, R 1368, wersja online: http://gateway-bayern.de/ VD16+R+1368 (dostęp: 3.09.2021).

${ }^{25}$ Zob. także dokumenty z: Archiv der Stadt Speyer, Bestand 141 Nr. 1, Buch in die Prediger Kirch (Taufbuch-Predigerkirche-1593-1689), s. 20, 22, 37, 123, 125; Taufbuch St.-Georgen 1593-1689, s. 58, 138, 141, 142, 143, 149, 168, 202, https://www.thesaurus-personarum.de/kirchenbuecher/\#449-auswertungen-1529917001 (dostęp: 10.05.2021). Zob. także Görtz, 2015, s. 61-62. 
w liście wspomnianego wcześniej rostockiego teologa Davida Chyträusa do wybitnego prawnika, profesora uniwersytetu w Greifswaldzie, Joachima Stephana (1544-1623) (Eisenhart, 1893, s. 93) z marca 1593 roku, w którym wspomina się o planowanym ślubie Georga z Justiną (Chyträus, 1614, s. 960). Reich zawierał w tym czasie liczne znajomości z wieloma osobami, nie tylko z lokalnego środowiska intelektualistów. Być może jedną z nich był znany lekarz miejski z Heilbronnu, Jeremias Eisenmenger (zm. 1625), któremu omawiana przez nas postać wpisała się 19 sierpnia 1596 roku w położonej w Szwarcwaldzie miejscowości Bad Liebenzell do wypełnionego stu kilkudziesięcioma innymi notami sztambucha ${ }^{26}$.

Piękny wolumin pracy Andreasa Vesaliusa był bez wątpienia ozdobą bibliotecznych zbiorów Georga Reicha, chociaż niestety nie znamy szczegółowych informacji o jego kolekcji, która w związku z wykształceniem i profesją właściciela była zapewne w główniej mierze wypełniona książkami prawniczymi. Po śmierci Georga opisywany egzemplarz znalazł prawdopodobnie kolejnego posiadacza. Nie mamy wiedzy, czy Reich zmarł bezpotomnie, jeśli tak było, to niewykluczone, że wolumin z rąk wdowy trafił do zbiorów jednego z członków jej rodziny, w której istniały silne tradycje medyczne. Lekarzami byli zarówno brat jej ojca, Marcus Peifer (Pfeiffer, zm. w 1582 roku) ${ }^{27}$, profesor medycyny pracujący w Lipsku, jak i dziadek ze strony matki, Blasius Grünewald (zm. około 1577 roku) — osobisty lekarz na dworze elektorskim Saksonii (Jöcher, 1751, szp. 1346; Krebs, Schwanitz, 2013). Być może jednak jeszcze za życia Georga książka została przekazana w zupełnie inne miejsce. Raczej pewne jest, że nie zasiliła ona zbiorów Biblioteki Uniwersyteckiej w Greifswaldzie, gdzie profesorem był jego pierwszy właściciel, bowiem nie rejestruje jej katalog tej placówki, opublikowany przez Johanna Karola Dähnerta w 1775 roku. Odnotowano tam natomiast egzemplarz pierwszego wydania Fabricae Vesaliusa ${ }^{28}$ oraz kilka innych prac wielkiego brukselskiego anatoma, w tym również lejdejską edycję Opera omnia anatomica et chirurgica z 1725 roku (Daehnert, 1775, s. $844^{29}$ ).

Co działo się z omawianym woluminem Fabricae, gdy przestał być własnością Georga Reicha młodszego, trudno będzie ustalić. Nie dostarczy nam w tym

26 Zob. portal Repertorivm Alborvm Amicorvm. Internationales Verzeichnis von Stammbüchern und Stammbuchfragmenten in öffentlichen und privaten Sammlungen, opracowany przez Department Germanistik und Komparatistik der Friedrich-Alexander-Universität Erlangen-Nürnberg, https://raa.gf-franken.de/de/suche-nach-stammbucheintraegen.html?permaLink=1570_eisenmenger;72 (dostęp: 12.06.2021).

27 Zob. portal Frühneuzeitliche Ärztebriefe des deutschsprachigen Raums (1500-1700), Bayerische Akademie der Wissenschaften. Institut für Geschichte der Medizin, www.aerztebriefe.de/ pe/00021573 (dostęp: 12.06.2021).

28 Być może chodzi o egzemplarz opisany jako zaginiony podczas II wojny światowej; zob. Margócsy, Somos, Joffe, 2018, s. 163.

29 W katalogu tym Fabrica z 1543 roku znalazła się pod poz. 48153. 
względzie żadnych wskazówek sama książka, brak na niej bowiem śladów dokumentujących jej dalszą wędrówkę w okresie aż do 1802 roku. To właśnie wówczas egzemplarz wesaliańskiego podręcznika trafił do rąk niezwykle ciekawej postaci Śląska Cieszyńskiego, jezuity Leopolda Jana Szersznika, na co wskazuje kolejna zapiska proweniencyjna, skreślona właśnie w tym roku, która brzmi: „Leopoldi Scherschnick m[anu] p[ropria] $18024 \mathrm{fl}$ '. Została ona ulokowana u dołu ozdobnej winiety, zawierającej dane o autorze i tytule dzieła na karcie tytułowej. Prawdopodobne okoliczności jego nabycia przez księdza Szersznika oraz szczegółowy opis woluminu, wraz $\mathrm{z}$ analizą śladów jego wykorzystywania ${ }^{30}$, zostaną zaprezentowane w drugiej części niniejszego artykułu.

\section{BIBLIOGRAFIA}

\section{ŹRÓDŁA INTERNETOWE}

Frühneuzeitliche Ärztebriefe des deutschsprachigen Raums (1500-1700), Bayerische Akademie der Wissenschaften. Institut für Geschichte der Medizin, www.aerztebriefe.de.

Herold, J., Magin, Ch. (2012). DI 77, Greifswald, Nr. 243\%. Deutsche Inschriften Online. https:// www.inschriften.net/greifswald/inschrift/nr/di077-0243.html?tx_hisodat_sources\%5Bac tion $\% 5 \mathrm{D}=$ show\&tx_hisodat_sources $\% 5 \mathrm{Bcontroller} \% 5 \mathrm{D}=$ Sources $\& \mathrm{cHash}=\mathrm{c} 263 \mathrm{f} 2 \mathrm{~b} 70 \mathrm{~b} 3 \mathrm{f} 9 \mathrm{a}$ 4b842c3a6e2d904d57\#content.

Kleczek, K. (2018, 18 maja). De humani corporis fabrica libri septem. Najstynniejsze XVI-wieczne dzieło o anatomii człowieka, [wystawa i prelekcja w Książnicy Cieszyńskiej z cyklu Cymelia i osobliwości w zbiorach Książnicy Cieszyńskiej, 2018]. https://kc-cieszyn.pl/de-humani-corporis-fabrica-libri-septem-najslynniejsze-xvi-wieczne-dzielo-o-anatomii-czlowieka/.

Repertorivm Alborvm Amicorvm. Internationales Verzeichnis von Stammbüchern und Stammbuchfragmenten in öffentlichen und privaten Sammlungen, Department Germanistik und Komparatistik der Friedrich-Alexander-Universität Erlangen-Nürnberg, https://raa.gf-franken.de/de/startseite.html.

Thesaurus Personarum. Pfälzische Personengeschichte des 16. bis 18. Jahrhunderts, Hans-Helmut Görtz, https://www.thesaurus-personarum.de.

\section{RĘKOPISY}

„Album Academiae Vitebergensis”, Universitäts- und Landesbibliothek Sachsen-Anhalt, sygn. Yo (2). „Matricula Academiae Rostochiensis: [1419-1760]”, Universitätsarchiv Rostock, sygn. 1.8 Matrikelbücher.

\section{STARE DRUKI}

Balthasar, J.H. von (1725). Andere Sammlung Einiger zur Pommerischen Kirchen-Historie gehörigen Schriften. Welche zur Erlaüterung und Vermrhrung der gedruckten Pommorischen Chronicken mit möglichstem Fleiss und Treue nebst beygefügten Anmerckungen... Greifswald: s.n.

${ }^{30}$ Egzemplarz posiada dość liczne vestigia lecturae, głównie w postaci podkreśleń oraz drobnych not marginalnych. 
Chyträus, D. (1599). Operum tomus quartus, Saxonia, ab anno Christi 1500. usque ad 1599. Recognita et... aucta... Lipsiae: Sumptibus Henningi Grosii.

Chyträus, D. (1614). Epistolae... Hanoviae: Typis Wechelianis, apud haeredes Ioannis Aubrii.

Cronenburger, J.M., Reich, G. (1591). Theses de solutione et acceptilatione quas... d. Iohanne Michaele Cronenburgero, SS. LL. Licent. Dictatore, subsidiariam operam benignè praestante, in ... IC. Agrippinensis Academiae collegio: Anno M.D. XC. reparatae salutis, XIV. Kalend. Aug. publicè defendere conabitur Georgius Reich Pomeranus. Coloniae Agrippinae: excudebat Ioannes Waldorf.

Daehnert, I.C. (1775). Academiae Grypeswaldensis Bibliotheca. Catalogo auctorum et repertorio reali universali descripta..., Tomus 2. Grypeswaldiae: A. F. Röse.

Etwas von gelehrten Rostockschen Sachen, für gute Freunde, Drittes Jahr MDCCXXXIX. (1739). Rostock: gedruckt bey Martin Warningck.

Etwas von gelehrten Rostockschen Sachen, für gute Freunde, Vierdtes Jahr MDCCXL. (1740). Rostock: gedruckt bey Martin Warningck.

Gruterus, J. (1612). Delitiae poetarum Germanorum huius superiorisque aevi illustrium: P. 1. Francfurti: Hoffmann.

Günther, S. (1608). Thesaurvs Practicantivm: Omnibvs In Imperialis Camerae Judicio Postulantibus, caussasve agentibus, summè expetendus: Cum rerum notabiliorum Indice locupletissimo. Spira: sumptibus authoris \& Heliae Kembachij.

Jöcher, C.G. (Hrsg.). (1751). Allgemeines Gelehrten-Lexicon, Bd. 3. Leipzig: Johann Friedrich Gleditschens Buchhandlung.

Lilienthal, M. (Hrsg.). (1725). Erleutertes Preußen, oder auserlesene Anmerkungen über verschiedene, zur Preussischen Kirchen-, Civil- und Gelehrten-Historie gehörige besondere Dinge, Woraus die bissherigen Historien Schreiber theils ergäntzet, theils verbessert, auch viele unbekannte Historische Wahrheiten ans Licht gebracht werden, Bd 3. Königsberg.

Ludolf, G.M. de. (1741). De jure camerali commentatio sistematica, ex fontibus legum publicarum et recensus visitationis novissimae concinnata... Wetzlariae: typis Nicolai Ludovici Winckleri.

Reich, G. (1587). Theses de usucapionibvs et praescriptionibus, qvas D. O. M. A. praeside... Dn. Lvdovico Person, I.V.D. defendere conabitur Georgivs Reich, Gryphs: Pommer... Witebergae: Ex typographia Simonis Gronenbergij.

Reich, G. (1593). Prima pars conclusionum repet. in cap. episcop. vel abbat. etc. in usib. feud. lib. I. tit. 6... in celeberrima Academia Vvitebergensi publicè defendere conabitur, Georgius Reich I. V. D. Respondente M. Friderico Tilemanno, Witebergensi. Witebergae: Typis Zachariae Lehmanni.

Reusner, N. (1594). Operum Nicolai Reusneri Leorini Silesii... Pars quarta continens Anagrammatvm Libros IX... Ienae: Typis Tobiae Steinmanni.

Scheffel, Ch.S. (1756). Vitae professorum medicinae qui in Academia Gryphiswaldensi a primis ejus initiis usque ad finem anni ipsius saecularis tertii vixerunt. Gryphiswaldiae: Typis Struckianis.

Vesalius, A. (1543). De Humani Corporis Fabrica Libri septem. Basileae: ex officina Joannis Oporini. Vesalius, A. (1555). De Humani Corporis Fabrica Libri septem. Basileae: ex officina Joannis Oporini.

\section{OPRACOWANIA WSPÓŁCZESNE (WIEK XIX-XXI)}

Album Academiae Vitebergensis ab a. Ch. MDII usque ad a. MDCII ... Sub auspiciis Bibliothecae Universitatis Halensis ex autographo editum. Vol. 2. (1894). Halis: Sumptibus Maximiliani Niemeyeri. 
Anselmino, O. (1906). Nachrichten von früheren Lehrern der Chemie an der Universität Greifswald. Mitteilungen aus dem Naturwissenschaftlichen Verein für Neu-Vorpommern und Rügen in Griefswalds, 38, 105-140.

Armstedt, R. (1911). Geschichte der Kneiphöfischen Gymnasiums zu Königsberg in Pr., Th. 2. Königsberg: Hartungsche Buchdrukerei.

Balthasar, A., Dinnies, J.A., Gesterding, C. (1868). Pommersche Genealogien: nach urkundlichen Quellen und den Sammlungen..., Bd. 2. Greifswald: Gesellschaft für Pommersche Geschichte und Alterthumskunde.

Besch, T. (1897). Friedrich von Heydeck. Ein Beitrag zur Geschichte der Reformation und Säkularisation Preußens. Altpreußische Monatsschrift, 34, [473]-535.

Bezzel, I. (Bearb.). (1983-2000). Verzeichnis der im deutschen Sprachbereich erschienenen Drukke des 16. Jahrhunderts, Bd. 1-24. Stuttgart: Anton Hiersemann Verlag.

Bieńkowska, B. (1998). Leopold Jan Szersznik - fundator biblioteki publicznej w Cieszynie. W: Łaskarzewska, H., Bad'urová, A. Ks. Leopold Jan Szersznik znany i nieznany. Materiaty z konferencji naukowej, Cieszyn, 6-7 listopada 1997 (ss. 138-150). Cieszyn-Warszawa: Książnica Cieszyńska, Polskie Towarzystwo Bibliologiczne.

Braun, W. [et al.], (Hrsg.). (1956). Festschrift zur 500-Jahrfeier der Universität Greifswald 17.10.1956, Bd. 2. Greifswald: Ernst Moritz Arndt-Universität.

Buchhester, D. (2015). Die Familie der Fürstin. Die herzoglichen Häuser der Pommern und Sachsen im 16. Jahrhundert. Erziehung, Bücher, Briefe. Frankfurt am Main: Peter Lang.

Caesar, C.I., (Hrsg.). (1879). Diem natalem augustissimi et potentissimi imperatoris ac regis Guilelmi I. ab Academia Marburgensi die XXII. m. Martii anni MDCCCLXXIX oratione in exedra pristini hippodromi habenda celebrandum indici Carolus Iulius Caesar... Inest Catalogi studiosorum scholae Marpurgensis cum Annalibus brevibus coniuncti particula septima. Marburgi: Typis Academicis Roberti Friedrich.

Chlebus, E. (2016). Dwie oprawy Tomasza Krügera z księgozbioru elbląskiego patrycjusza Andrzeja Morenberga. W: Imańska, I., Wagner, A. (Red.). Dawnych ksiag niesyty. Tom studiów dedykowanych profesorowi Januszowi Tondelowi na siedemdziesięciolecie urodzin (ss. 205221). Toruń: Wydawnictwo Naukowe Uniwersytetu Mikołaja Kopernika.

Corsten, S., Fabian, B., Kloth, K., Heitz, G., Treuter, I.-M., Krause, F. (1996). Handbuch der historischen Buchbestände in Deutschland. Bd. 16. Hildesheim: Olms-Weidmann.

Durling, R.J. (1965). Conrad Gesner's Liber amicorum. Gesnerus. Swiss Journal for the History of Medicine and Science, 22(3-4), 134-159.

Eisenhart, J.A. Ritter von (1887). Peifer, David. In: Allgemeine Deutsche Biographie, Bd 25 (ss. 321324). https://www.deutsche-biographie.de/pnd116073659.html\#adbcontent.

Eisenhart, J.A. Ritter von (1893). Stephani, Joachim. In: Allgemeine Deutsche Biographie, Bd 36 (s. 93). https://www.deutsche-biographie.de/pnd104319348.html\#adbcontent.

Erler, G. (Hrsg.). (1910). Die Matrikel und die Promotionsverzeichnisse der Albertus-Universität zu Königsberg i. Pr. 1544-1829, Bd. 1. Die Immatrikulationen von 1544-1656. Leipzig: Verlag von Duncker \& Humboldt.

Ewert, G., Ewert, R. (2013). Hochschulmedizin in Greifswald von der Universitätsgründung (1456) bis zum Universitätskrankenhaus (1859). Berlin: Pro Business GmbH.

Favro, A. (1911). Atti della Nazione Germanica Artista nello Studio di Padova, vol. 1. Venezia: A spese della Società.

Foerstemann, C.E., (Ed.). (1841). Album Academiae Vitebergensis ab a. Ch. MDII usque ad a. MDLX. Lipsiae: Sumptibus et typis Caroli Tauchnitii. 
Freytag, H. (1903). Die Preussen auf der Universität Wittenberg und die nichtpreussischen Schüler Wittenbergs in Preussen von 1502 bis 1602. Eine Festgabe zur vierhundertjährigen Gedächtnisfeier der Gründung der Universität Wittenberg. Leipzig: Verlag von Doncker \& Humboldt.

Friedlaender, E., Malagola, C. (Ed.). (1887). Acta nationis Germanicae Universitatis Bononiensis ex archetypis tabularii malvezziani. Berolini: Typis et impensis Georgii Reimeri.

Friedländer E. [et al.] (Hrsg.). (1893). Aeltere Universitäts-Matrikeln, II. Universität Greifswald, Bd. 1. 1456-1645. Leipzig: Verlag von S. Hirzel.

Gebser, A.R. (1835). Der Dom zu Königsberg in Preußen: eine kirchen- und kunstgeschichtliche Schilderung. Geschichte der Domkirche zu Königsberg und des Bisthums Samland: mit einer ausführlichen Darstellung der Reformation im Herzogthum Preußen. Königsberg: Gedruckt in der Hartungschen Hofbuchdruckerey.

Gesterding, C. (1829). Ueber Greifswaldische Stipendien für Studirende als zweite Fortsetzung des Beitrages zur Geschichte der Stadt Greifswald. Greifswald: In Commission bei Ernst Mauritius.

Görtz, H.H. (2015). Reichskammergerichtspersonal und andere Personen in den Taufbüchern von Predigerkirche und St. Georgen zu Speyer 1593-1689. Speyer: Selbstverlag des Autors in Verbindung mit dem Historischen Verein der Pfalz, Bezirksgruppe Speyer.

Görtz, H.H. (2018). Nomina Spirensium Lutheranorum. Personen aus Speyer und außerhalb in den Taufbüchern von Predigerkirche und St. Georgen 1593-1689. Personenregister. Freinsheim. https://www.thesaurus-personarum.de/download/49/auswertungen/831/nsl-3-orte.pdf.

Heinrich, A. (2004). Repertorium codicum manuscriptorum in caesareo-regia Bibliotheca Scherschnickiana Teschinii. Wrocław: Centrum Badań Śląskoznawczych i Bohemistycznych Uniwersytetu Wrocławskiego.

Hofmeister, A. (Hrsg.). (1891). Die Matrikel der Universität Rostock, Bd. 2. (Mich. 1499-Ost. 1611). Rostock 1891. http://purl.uni-rostock.de/rosdok/ppn574598650.

Jaster, S. (2008). Die medizinische Fakultät der Albertus-Universität und ihre bedeutendsten Vertreter im 16. Und 17. Jahrhundert. In: Marti, H., Komorowski, M. (Hrsg.). Die Universität Königsberg in der Frühen Neuzeit (ss. [42]-76). Köln: Böhlau Verlag.

Jędrzejewski, K.S. (2013). Andreas Vesalius i jego wielkie dzieło: De humani corporis fabrica. Folia Medica Lodziensia, 40(2), 155-206.

Jügelt, K.H. (1995). Magister Georg Reiche (1495-1565), Prediger der Nikolaikirche, und die Universität Rostock. In: Jakubowski, P., Münch E. (Hrsg.). Wissenschaftliche Tagung Universität und Stadt: anläßlich des 575. Jubiläums der Eröffnung der Universität Rostock (ss. 103-114). Rostock: Die Universität.

Jügelt, K.H. (1999). Reiche, Riccius, Ricke, gen. Plutus oder Pluto, Georg (Jörgen, Jürgen) [Biographie]. In: Pettke, S. (Hrsg). Biographisches Lexikon für Mecklenburg (ss. 193-195) Bd. 2. Rostock: Schmidt-Römhild.

Jügelt, K.H. (2014). Magister Georg Reiche (1495-1565), Pastor der Nikolaikirche zu Rostock, und die Universität Rostock. In: Zepf, R., Siebert, S. (Hrsg.). Karl-Heinz Jügelt. Opera bibliothecarii. Ausgewählte Beiträge zur Geschichte von Universität und Universitätsbibliothek Rostock - Festgabe zum 80. Geburtstag am 11. September 2014 (ss. 40-52). Rostock: Universitätsbibliothek Rostock.

Kamptz, C.C.A.H. von. (1802). Darstelung des Präsentations-Recht zu den Assessoraten am Kaiserlichen und Reichs-Kammergerichte. Göttingen: Heinrich Dieterich.

Keussen, H. (vorb.), Nyassi, U., Wilkes, M. (bearb.). (1981). Die Matrikel der Universität Köln, Bd. 4. 1559-1675. Düsseldorf: Droste Verlag GmbH.

Kleczek, K., Rusnok, A. (2010). Książki, które stworzyty Europę. [Katalog wystawy], Cieszyn: Książnica Cieszyńska. 
Knod, G.C. (1899). Deutsche Studenten in Bologna (1289-1562). Biographischer Index zu den Acta nationis germanicae Universitatis Bononienses. Berlin: R.v.Decker, G. Schenck.

Koppmann, K. (1890). Die Prediger zu Rostock im 16 Jahrhundert. Beiträge zur Geschichte der Stadt Rostock, 1(3), 15-77.

Kosegarten, J.G.L. (1857). Geschichte der Universität Greifswald: mit urkundlichen Beilagen. Bd. 1. Greifswald: C. A. Koch.

Krabbe. O. (1870). David Chyträus. Rostock: Stiller'sche Hofbuchhandlung.

Krause, K.E.H. (1888) Reiche, Georg. In: Allgemeine Deutsche Biographie, Bd. 27 (ss. 651-652). https://www.deutsche-biographie.de/pnd138434182.html\#adbcontent.

Krebs. H.D., Schwanitz, H. (2013). David Peifer der Ältere. Sächsische Biografie. Hrsg. vom Institut für Sächsische Geschichte und Volkskunde e.V. https://saebi.isgv.de/biografie/David Peifer_d._\%C3\%84._(1530-1602).

Krüger, N. (2003). Die Inkunabeln der Universitätsbibliothek Rostock. Mit den Inkunabeln der Landesbibliothek Mecklenburg-Vorpommern in Schwerin und der Kirchenbibliothek Friedland. Wiesbaden: Harrassowitz Verlag.

Kudélka, M. (1957). Leopold Jan Šeršník (1747-1814). Život a dílo. Ostrava: Krajské nakladatelství (Publikace Slezského Studijního Üstavu v Opavě; Svazek 20).

Kuhnert, E. (1926) Geschichte der Staats- und Universitätsbibliothek zu Königsberg. Von ihre Begründung bis zum Jahre 1810. Leipzig: Karl W. Hiersemann.

Kusche, S. (2005). Friedrich Wilhelm I. In: Sächsische Biografie, hrsg. vom Institut für Sächsische Geschichte und Volkskunde e.V. https://saebi.isgv.de/files/saebi/pdf/1551_Friedrich Wilhelm_I._Herzog_von_Sachsen-Weimar_(1562-1602).pdf.

Lange, M. (2014). Rostock lernt Hebräisch. Die Hebräisch-Grammatik Elia Levitas (1469-1549) in der Übersetzung des christlichen Kosmographen und Hebraisten Sebastian Münster (14881552) aus dem Bestand der Universitätsbibliothek Rostock. In: Boeck, G., Lamme, H.U. (Hrsg.). Jüdische kulturelle und religiöse Einflüsse auf die Stadt Rostock und ihre Universität (ss. [41]-56). Rostock 2014.

Lange, M. (2018). Ein Meilenstein der Hebraistik. Der „, Sefer ha-Bachur“ Elia Levitas in Sebastian Münsters Übersetzung und Edition. Leipzig: Evangelische Verlagsanstalt.

Magin Ch. (2010). Akademische Epigraphik? Zu den historischen Inschriften der Universitäten Rostock und Greifswald. In: Lammel H.U., Boeck G. (Hrsg.). Tochter oder Schwester - die Universität Greifswald aus Rostocker Sicht. Referate der interdisziplinären Ringvorlesung des Arbeitskreises „Rostocker Universitäts- und Wissenschaftsgeschichte“ im Wintersemester 2006/07 (ss. [85]-112). Rostock: Universität Rostock.

Margócsy D., Somos, M., Joffe S.N. (2018). The Fabrica of Andreas Vesalius. A Worldwide Descriptive Census, Ownership, and Annotations of the 1543 and 1555 editions. Leiden, Boston: Brill.

Nicollier-De Weck, B. (1995). Hubert Languet (1518-1581): un réseau politique international, de Melanchthon à Guillaume d'Orange. Genève: Librairie Droz.

Nierzwicki, K. (2016). Warszawski egzemplarz „De humani corporis fabrica” Andreasa Vesaliusa (Bazylea 1555) ze zbiorów Biblioteki Narodowej. Przyczynek do dziejów recepcji anatomii wesaliańskiej w Polsce. W: Imańska, I., Wagner, A. (Red.). Dawnych ksiag niesyty. Tom studiów dedykowanych profesorowi Januszowi Tondelowi na siedemdziesięciolecie urodzin (ss. 167-203). Toruń: Wydawnictwo Naukowe Uniwersytetu Mikołaja Kopernika.

Nierzwicki K. (2019a). W poszukiwaniu anatomicznego traktatu De humani corporis Fabrica Andreasa Vesaliusa (Basel 1543, 1555) w Gdańsku. Biblioteka, 23(32), 167-207.

Nierzwicki K. (2019b). Chełmiński egzemplarz „De humani corporis fabrica” Andreasa Vesaliusa (Bazylea 1555) w zbiorach Biblioteki Uniwersyteckiej w Toruniu. W: Fedorowicz-Kruszewska, M., Cyrklaff-Gorczyca M., Kruszewski, T. (Red.). W świecie bibliologii i informatologii. Księga dedykowana Profesor Bronisławie Woźniczce-Paruzel w 70. rocznicę urodzin. Praca zbiorowa (ss. [59]-98). Toruń: Wydawnictwo Naukowe Uniwersytetu Mikołaja Kopernika. 
Nierzwicki K. (2021a). Andreas Vesalius i jego „De humani corporis fabrica” w polskich zbiorach bibliotecznych. Wiadomości Akademickie, 81, 2-11.

Nierzwicki, K. (2021b). Królewiecki egzemplarz „De humani corporis fabrica” Andreasa Vesaliusa w zbiorach Biblioteki Wyższego Seminarium Duchownego Metropolii Warmińskiej „Hosianum” w Olsztynie, Z Badań nad Książka i Księgozbiorami Historycznymi, 15, 29-55.

Nutton, V. (2014). Historical introduction. In: Garrison, D.H., Hast, M.H. (Ed.). Vesalius, A., The Fabric of the Human Body. An Annotated Translation of the 1543 and 1555 Editions of „,De Humani Corporis Fabrica Libri Septem” (ss. LXXV-CIII). Basel: S. Karger.

Peters, J. (2000). Humanistische und barocke Quellen zur Geschichte Schlesiens in der Bibliothek Leopold Johann Scherschniks (1747-1814): ein Bericht über die Książnica Cieszyńska. In: Kosellek, G. (Hrsg.). Oberschlesische Dichter und Gelehrte vom Humanismus bis zum Barock (ss. [449]-459). Bielefeld: „Aisthesis“.

Petersdorff, H. (1887). Pommersche Studierende auf der Universität Heidelberg. Vierteljahrsschrift für Heraldik, Sphragistik und Genealogie, 15, 207-222.

Rotermund H.W. (1819). Fortsetzung und Ergänzungen zu Christian Gottlieb Jöchers Allgemeinem Gelehrten-Lexicon, Bd 6. Bremen: bey Johann Georg Heyse.

Schwarz, H.D. (2001). Placotomus, Johann. In: Neue Deutsche Biographie, Bd. 20 (s. 495f.). https:// www.deutsche-biographie.de/pnd12446808X.html\#ndbcontent.

Serczyk, J. (1994). Albertyna. Uniwersytet w Królewcu (1544-1945). Olsztyn: Ośrodek Badań Naukowych im. Wojciecha Kętrzyńskiego.

Sidorowicz-Mulak, D., Wagner, A. (2015). Dzieło Vesaliusa w oprawie Mistrza Dawida a problem początków księgozbioru króla Zygmunta Augusta. Roczniki Biblioteczne, 59, 3-24.

Siek, B., Szarszewski, A. (Oprac.). (2015). ,Vitae medicorum Gedanensium” Ludwiga von Hammena i Valentina Schlieffa. Gdańsk: Wydawnictwo Athenae Gedanenses.

Skrobacki, A. (1969). Polacy na wydziale lekarskim Uniwersytetu w Królewcu. Olsztyn: Stowarzyszenie Społeczno-Kulturalne Pojezierze.

Sokół, S. (1960). Medycyna w Gdańsku w dobie Odrodzenia. Wrocław: Zakład Narodowy im. Ossolińskich - Wydawnictwo PAN.

Spyra, J., Chromik, G. (Wyd.). (2014). Malo invidiam quam misericordiam. Wybór pism i dokumentów dotyczacych Leopolda Jana Szersznika. Cieszyn: Książnica Cieszyńska.

Sztuchlik, J., Picha, J. (2002). Literatura medyczna w zbiorach cieszyńskich lekarzy i farmaceutów w XVIII/XIX w. na podstawie zapisów proweniencyjnych w Bibliotece Leopolda Jana Szersznika. Medycyna Nowożytna, 9(1/2), 165-176.

Thümmel, H. G. (Hrsg.). (2002). Geschichte der Medizinischen Fakultät Greifswald. Geschichte der Medizinischen Fakultät von 1456 bis 1713 von Christoph Helwig D. J. und das Dekanatsbuch der medizinischen Fakultät von 1714 bis 1823. Stuttgart: Franz Steiner Verlag.

Toepke, G. (Hrsg.). (1886). Die Matrikel der Universität Heidelberg von 1386 bis 1662, Bd 2. 15541662. Heidelberg: Selbstverlag des Herausgeber.

Tondel, J. (1992). Biblioteka Zamkowa (1529-1568) księcia Albrechta Pruskiego w Królewcu. Toruń: Wydawnictwo Naukowe Uniwersytetu Mikołaja Kopernika.

Tschackert, P. (Hrsg.). (1890). Urkundenbuch zur Reformationsgeschichte des Herzogthums Preussen, Bd. 2. Leipzig: S. Hirzel.

Urban, W. (2000). Polonica w Liber amicorum Konrada Gesnera. Res Historica, 10, 217-219.

Wąs, G. (2011). Rozmowy chrześcijańskie w nurcie reformacji. Legniccy i pruscy ewangelicy wobec wczesnoreformacyjnych problemów. Wrocław: Wydawnictwo Uniwersytetu Wrocławskiego.

Zwiercan, M. (2003). Katalog średniowiecznych rękopisów Książnicy Cieszyńskiej, Wrocław: Centrum Badań Śląskoznawczych i Bohemistycznych Uniwersytetu Wrocławskiego. 
KRZYSZTOF NIERZWICKI

COPY OF THE SECOND EDITION OF DE HUMANI CORPORIS FABRICA

BY ANDREAS VESALIUS (BASEL 1555),

FROM THE COLLECTION OF THE CIESZYN LIBRARY.

PART 1: IN THE COLLECTIONS OF EZECHIAS AND GEORG REICH (2ND HALF OF 16TH CENTURY - BEGINNING OF THE 17TH CENTURY)

\section{Summary}

The author has attempted to trace the provenance of a copy of the second edition of De humani corporis fabrica by Andreas Vesalius (Basel, 1555), which is located in the Cieszyn Library. In the course of the research it was established that this volume belonged to at least three people: the ducal court doctor and professor of medicine at the University of Greifswald Ezechias Reich (1532-1572); his son, a doctor of law and assesor at the Reichskammergericht in Speyer Georg Reich the younger (1568-1616/1620), and then from 1802 to Leopold Jan Szersznik, a social activist and historian from Cieszyn, and the founder of the public library in Cieszyn.

KEY WORDS: Cieszyn, Cieszyn Library, Georg Reich the Elder, Ezechias Reich, Georg Reich the Younger, Leopold Jan Szersznik, Andreas Vesalius, De humani corporis fabrica 